\title{
PERSONNEL PROBLEMS IN THE ADMINISTRATION OF JUSTICE IN NIGERIA
}

Sir Adetokunbo Ademola*

Since the year 1955, the personnel problems in the administration of justice in Nigeria have become more and more complex. From one particular angle, to which I shall have cause to refer later, the problems will in about ten years' time become more and more acute. Before I955, Nigeria had what can be called a unified judiciary. There was one Chief Justice for the whole country, with a number of puisne judges under him, as well as magistrates, registrars, and the clerical staff. Judges and magistrates were recruited from the Colonial Judicial Service. Many of them were expatriates, with a good number of Africans. The registrars and the clerical staff have always been Africans. Every member of the staff under the Chief Justice, be he a judge, a magistrate, a registrar, or on the clerical staff, was expected to serve in any part of Nigeria; and so it was that a judge who served one year in Lagos or in Western Nigeria would find himself in the North or in the East the following year.

When it was decided that Nigeria should adopt a federal form of government, there were some-particularly in the judiciary-who advocated that the judiciary should not be regionalized and that a unitary judiciary should continue to serve the country. The politicians, however, thought otherwise, and the view taken was that if the country was to be regionalized, it must be a full regionalization including the judiciary. The argument that a unitary judiciary would serve to bind the different regions or states together more closely was dismissed, and the country was harnessed for a regionalized judiciary.

The first difficulty the department had to encounter was the distribution of staff to the three different Regions and to Lagos. By the end of 1955, however, everybody's nose was at the grindstone in his Region, and all was well.

\section{Personnel}

The machinery of justice works with many wheels. Quite apart from judges and magistrates, many more are employed in the administration of justice; and their duties vary as does their status. There are the Registrars in different grades, the Sheriff, the Director of Prisons, and their clerical and other staff, and this is by no means an exhaustive list. Their position or responsibility, high or low as it may be, is not to be taken as a conclusive index to their importance in the general scheme of the administration of justice. The ordinary court interpreter can be a veritable factor for miscarriage of justice, if he chooses to be corrupt.

* B.A. (Hons.) 1931, M.A. (Hons.) 1934, Cambridge University, Honorary Bencher of the Middle Temple, Barrister at Law. Chief Justice of the Federation, Federal Supreme Court of Nigeria, since 1958. 
The judge-and the magistrate, of course-is the central figure in the scheme of things; and around him the whole machinery of justice revolves. If he is careful and conscientious, very little can go amiss because not only is he charged with the duty of decision making but the administrative machinery must be supervised carefully by him, unless, of course, he is in the headquarters. There, the Chief Justice himself is personally responsible for the administrative machinery. In this supervisory capacity, he is helped by a high officer known as the Chief Registrar, whose office is higher than that of a magistrate.

In a country with a written constitution like Nigeria, the judge occupies such a unique position as the arbiter of rights and duties, not only between citizen and citizen but also between the state and the citizen, and in a federal constitution, it may be added, as between the constituent regional states.

\section{Requisites of a good judge}

I have mentioned earlier the unique position of a judge in a country with a written constitution; this is more marked in a newly independent country. But however good and however democratic the constitution may appear to be, it has, in the last resort, to depend and be greatly influenced by the quality of its judges who have to give it interpretation. The more detached or impersonal the judge, the more likely will the intention of the framers of the constitution fructify.

This, of course, raises the all-important problem of recruitment. In this respect three important aspects have to be considered:

(i) the general problem of criteria on recruitment;

(ii) the problem of specialization and allocation;

(iii) the problem of efficiency and promotion.

In considering the general problem of criteria and selection, it must be borne in mind that the colonial powers have left behind in their former colonies their tradition and conception of justice. This has without doubt affected, to a large degree, the outlook on criteria. What are those qualities which make a good judge; what do you look for in a judge? That there is a unanimity of opinion on this cannot be doubted, although these qualities may be enhanced or impaired depending upon methods adopted in recruiting judges.

The basic qualities of a good judge are:

(a) Sound knowledge of the law. This hardly needs any amplification. A sound logical mind helps in the assimilation of this knowledge.

(b) The matter of detachment. A good judge should be objective in assessing facts. A judge should never allow his own personal feelings or his own preconceived notions to displace facts which have been proved before him.

(c) Sound common sense. It should be accepted that not all matters which come before a judge need only knowledge of the law. A judge must also be good 
on facts and his assessment of facts, i.e., evaluation of the evidence before him and deductions from facts. Common sense is an indispensable factor in the attributes of a good judge.

(d) A judge should be humane. This attribute, to my mind, plays an important role in the relation between the judiciary and the public. The humane element in the administration of justice has always strengthened the position of the judiciary in any country.

(e) Freedom from fear, prejudice, or corruption. Modern constitutions provide for the appointment, renewal of appointment, dismissal, general welfare, and promotion of judges; freedom from political or other influences are also of paramount importance.

Judges are paid reasonably good salaries in order to minimize the possibility of corruption. No matter how many freedoms there are, however, the determining factor indeed is the character of the judge himself.

The Nigerian outlook on recruitment is at present basically English. Whether this will change or not, it is difficult to say, but it is obvious that for some years this will remain so. A judge should be a lawyer with a reasonably long practice, sufficient to enable those among whom he functions to be able to assess the above qualities. There is something to be said in favor of the democratic system of election of judges in some of the states in the United States of America, but my view is that this is not likely to work in Nigeria; the man who wins an election is likely to have the least of the qualities already enumerated. What is more, there is also the grave danger of having to please supporters or sometimes the temptation of allowing the prospects of future election to interfere with the administration of justice. I have heard a judge from the United States say that he did not have to bother for the next three years, but after that time he must start to think of his future; it was no doubt said with humor and in jest, but such a position will undoubtedly not appeal to the African mind.

The method of selection may theoretically seem to be less democratic, but it appears to be on the whole a better system. The politicians are not in sympathy generally with any system which excludes their right to determine, but they always have a good word for an impartial judiciary.

\section{The problem of specialization and allocation}

Views differ as to whether judges should specialize, or whether the judicial system itself should departmentalize. On the whole, it is true that the legal knowledge and experience required of judges in the following courts are not the same: criminal court, civil court, land court, constitutional court, industrial court, and international court.

In medicine today, it is important to specialize, and it may be that one day we shall find very few general practitioners about. When the time comes that there is a 
dearth of general practitioners, the swing in that direction will undoubtedly start. In law, the general practitioner will for many years to come in Nigeria be the order of the day. In England, where a lawyer chooses early in his career whether he will practice in the chancery or the common law side, or in the criminal courts, it is easier from time to time to be in a position to appoint judges who are masters of, or who specialize in, different departments of the law. This undoubtedly makes for efficiency. When I visited a firm of legal practitioners in New York, I found no less than twenty-four lawyers, all specialists, each in his own branch of the law. A client who consults has his matter dealt with by a member of the firm suitable to his case. This is still unknown in Nigeria, where there are but few cases of partnership. It is hoped many more partnerships will spring or grow up. But even then, for the present, in Nigeria, a client consults a particular barrister because he is Mr. X, known to him in one way or another. He certainly does not wish his case handled by any other barrister but that barrister of his choice.

As with barristers, it is the same with judges in Nigeria. A judge does not specialize; he is trained to handle any case which comes before him; he has no choice. The Nigerian Constitution undoubtedly is somewhat complex. With the complex Federal Constitution, the problem of specialization for the Bench as well as the Bar may come earlier than expected; it is evident that a few lawyers are taking particular interest in constitutional matters before the courts. A "body of opinion" may soon grow up in that direction; a good few members of the Bar would specialize in Constitutional Law. This, to my mind, is frightfully important in a country with a written constitution. With specialization from the Bar, the Bench will have to think quickly. Specialization in Nigeria, however, is not likely to be on a large scale; it will be no more than in constitutional law and international law. It is doubtful if a separate Constitutional Court, as in Germany, will be introduced in Nigeria in the foreseeable future.

\section{Problems of efficiency and promotion}

Important considerations enter into this, particularly where, as in Nigeria, the judiciary is regionalized. Each Region tends to prefer the natives of the Region, and the problem is how to reconcile this fact with efficiency and a sense of responsibility. There is no doubt that an efficient judge who is a native of a Region is more likely to understand the psychology of his "locals" and thereby to have a distinct advantage over the others. But there is a definite threat to the impartial administration of justice from our undue stress of geographical or ethnological qualification for the Bench.

Similarly, there is the desire to give effect to the federal texture in a place like Nigeria through a mixed composition of the judiciary in Lagos, particularly in the Federal Supreme Court. This may be desirable-I myself doubt it-but it may easily be overstressed. It raises the problem that in an attempt to mix the Court, the best judges would not necessarily be promoted to the Federal Supreme Court. Allied to this is the problem of promotion from the lower Bench (magistrates) to the 
Bench (judgeship). It certainly will be a sad thing for Nigeria at present to attempt in any way to indulge in mixing any of the courts in the federal territory of Lagos. It seems reasonably certain that for the present the problem of a Mixed Court is not likely to gain favor with the Bar and with the people. I am well aware that a few people are not only thinking about it but are already talking about it. The idea will not, however, germinate, for the present, for reasons already mentioned; also because there are not as many qualified candidates in one or two of the Regions. In other parts of the world where the federal structure is reflected on the Bench, it has not produced a better result than the system of letting the best man have the job. This problem, I daresay, will be more and more difficult as the Federation gets older.

\section{Problems due to regionalization}

Regionalization of the judiciary has also brought in its wake the question of uniform standards. The Western Region of Nigeria-particularly that part of the West nearer to Lagos-and Lagos have produced three generations of lawyers. In the Eastern Region, there is an old, established bar in the very small town of Calabar, but otherwise present lawyers are the first generation at the bar. The Northern Region has only just started but it is running very fast in the race. Therefore, of the thousand legal practitioners in Nigeria, a great number are from the Western Region and Lagos.

So far there has not been any inter-regional transfer of judges. There is no reason why this should not happen; it might be easy in one or two Regions, but owing to the centrifugal tendencies of regional legislation, it may prove rather difficult in the future with some Regions.

\section{Unified Judicial System in Pan-African World}

The tendency to unify everything African is prevalent; it has been considered that a unification of the judicial system in Africa will be ideal. This is not going to be an easy matter. There is the problem of language which will undoubtedly be a stumbling block, quite apart from the difference in the judicial systems in the English-speaking territories in Africa and in the French-speaking territories.

These are but a few personnel problems in the administration of justice in Nigeria; they are not insurmountable. With the ability of the Nigerians to laugh at their own mistakes, and with our natural humor, there is hardly any doubt that these problems will soon be minimized. 